Institute of $\mathbf{F}_{\text {ood and }} \mathbf{A}_{\text {gricultural }} \mathbf{S}_{\text {ciences }}$

\title{
UF/IFAS Extension Soil Testing Laboratory (ESTL) Analytical Procedures and Training Manual ${ }^{1}$
}

Rao S. Mylavarapu and Elizabeth D. Kennelley ${ }^{2}$

\section{Contents}

\author{
Extension Soil Testing Laboratory: Mission \\ and Purpose
}

\section{Description of Offered Tests}

\section{Sample Submission}

How to Submit Samples

Sample Submission Forms

Supplies

\section{Sample Preparation}

\section{Analytical Procedures for Soil}

Soil Scooping

Soil pH (1:2 V/V)

Adams-Evans Buffer pH

Mehlich-1 Extractable P, K, Ca, Mg, Cu, Mn, and $\mathrm{Zn}$
Organic Matter

Walkley-Black Method

Loss-on-Ignition

Electrical Conductivity

Analytical Procedures for Container Media

Extraction Procedure

$\mathrm{pH}$

Electrical Conductivity (EC)

$\mathrm{NO}_{3}$

Water-Extractable P, K, Ca, Mg

Analytical Procedures for Calcareous Soils

AB-DTPA Extractable P

Analytical Procedures for Water

$\mathrm{pH}$

1. This document is Circular 1248, one of a series of the Soil and Water Science Department, Florida Cooperative Extension Service, Institute of Food and Agricultural Sciences, University of Florida. Original publication date: September 2002. Visit the EDIS Web Site at http://edis.ifas.ufl.edu.

2. Rao S. Mylavarapu, Assistant Professor, Nutrient Management Specialist and Director, UF/IFAS Extension Soil Testing Laboratory; Elizabeth D. Kennelley, Coordinator, UF/IFAS Extension Soil Testing Laboratory, Department of Soil and Water Science, Florida Cooperative Extension Service, Institute of Food and Agricultural Sciences, University of Florida, Gainesville, FL 32610.

The Institute of Food and Agricultural Sciences is an equal opportunity/affirmative action employer authorized to provide research, educational information and other services only to individuals and institutions that function without regard to race, color, sex, age, handicap, or national origin. For information on obtaining other extension publications, contact your county Cooperative Extension Service office. Florida Cooperative Extension Service/Institute of Food and Agricultural Sciences/University of Florida/Christine Taylor Waddill, Dean. 
Electrical Conductivity (EC)

Metals

Chloride $\left(\mathrm{Cl}^{-}\right)$

Carbonate Equivalent

Suspended Solids

\section{Analytical Procedures for Plants}

Standard Determination of $\mathrm{Ca}, \mathrm{Mg}, \mathrm{P}, \mathrm{K}, \mathrm{Na}$, $\mathrm{Mn}, \mathrm{Cu}, \mathrm{Fe}, \mathrm{Zn}$, and $\mathrm{B}$ in Plant Tissue

Total Kjeldahl Nitrogen (TKN) in Plant Tissue

Quality Control

\section{Laboratory Safety}

\section{References}

\section{Acknowledgements}

\section{Extension Soil Testing Laboratory: Mission and Purpose}

The University of Florida (UF), Institute of Food and Agricultural Sciences (IFAS), Extension Soil Testing Laboratory (ESTL) was established to serve the people of Florida with their soil, plant, and water testing needs for ensuring economically and environmentally sustainable crop production. The ESTL clientele receive accurate agricultural test results, interpretations and recommendations regarding appropriate rates, use of nutrients and nutrient management techniques developed for Florida.

\section{Mission Statement}

The mission of the UF/IFAS Extension Soil Testing Laboratory is :

"to serve the citizens of Florida, by providing appropriately selected soil, plant and water testing, interpretation and recommendations as an educational service through the Cooperative Extension Service to guide management decisions affecting lime and fertilizer use efficiency."
The ESTL provides chemical analyses of inorganic soils, container media, diagnostic plant tissue nutrients, and irrigation and household water samples for all Florida residents. Testing is restricted to samples originating from the state of Florida only. Requests for testing of animal manures should be sent to UF/IFAS Livestock Waste Testing Laboratory at the North Florida Research and Education Center Suwannee in Live Oak, FL. Testing of materials such as drinking water, sewage sludges, wastewater effluent, sludges from water-treatment facilities, hazardous chemical or biological tests of water or soil, or limestone are referred to other governmental or private laboratories.

\section{Purpose of this Manual and Intended Audience}

This Circular consists of revised portions from the IFAS Extension Soil Testing Laboratory Chemical Procedures and Training Manual (CIR 812), authored by Hanlon, Gonzalez and Bartos, which has been withdrawn. The procedures described in this manual reflect the current methodologies for agricultural testing offered by the UF/IFAS ESTL. This Circular replaces previous information that is contained in other IFAS publications. The ESTL services are offered as a part of the Nutrient Management Extension Program in fulfillment of the public service mandate of the landgrant university mission. Only tests that have been shown through research/experience to assist in crop-management decisions are offered by the ESTL to Florida residents. It is the intention of the Cooperative Extension Service to offer only analytical procedures whose results can be interpreted, and thus, render assistance with management decisions involving water, plants, soils, and nutrients.

A small number of diagnostic samples submitted by county or state-wide Extension IFAS faculty may be tested free of charge. A limited number of similar services may be extended to IFAS researchers if needed, to assist researchers in making nutrient management decisions when establishing field research plots.

Superscripted numbers throughout the text below denote the corresponding publication in the References section. 


\section{Description of Tests Offered}

\section{Commercial Crop Production on Mineral Soils (Agronomic, Vegetable, Ornamental, and Fruit Crops)}

The ESTL uses Mehlich-1 extraction procedure for extracting soil samples in preparation for further soil-fertility analyses. The Mehlich-1 extraction solution, also referred to as the "dilute double acid" extractant $\left(0.05 \mathrm{M} \mathrm{HCl}+0.0125 \mathrm{M} \mathrm{H}_{2} \mathrm{SO}_{4}\right)$, is intended for use in extracting weathered soils that have cation exchange capacities of less than $10 \mathrm{cmol}$ $\mathrm{kg}^{-1}$ and whose soil $\mathrm{pH}$ is less than 7.0. The Mehlich-1 extraction method is not suitable for the extraction of alkaline soils. ${ }^{21}$ For alkaline soils, recommended extractant in Florida is ammonium bicarbonate-DTPA (AB-DTPA).

The ESTL offers a standard soil-fertility test for noncalcareous inorganic soils. The standard test includes analyses for soil $\mathrm{pH}$ and macronutrients phosphorus $(\mathrm{P})$, potassium $(\mathrm{K})$, calcium $(\mathrm{Ca})$, and magnesium $(\mathrm{Mg})$ levels in the soil. The ESTL does not test for soil nitrogen $(\mathrm{N})$ as there is no reliable soil test for predicting $\mathrm{N}$ availability to the plants. If a crop code is included on the analysis request form, a test for Buffer $\mathrm{pH}$ may be determined using Adams-Evans Buffer solution ( $\mathrm{pH} 8.00$ ), if the soil $\mathrm{pH}$ obtained is lower than the Target $\mathrm{pH}$ of the crop specified. The Target $\mathrm{pH}$ for a crop is that soil $\mathrm{pH}$ at which optimal crop performance and yield is achieved and is therefore specific to the crop. Buffer $\mathrm{pH}$ will not be determined if no crop is specified on the sample submission form or if the difference between the soil $\mathrm{pH}$ and the target $\mathrm{pH}$ is less than 0.2 $\mathrm{pH}$ units or if the soil $\mathrm{pH}$ exceeds the target $\mathrm{pH}$. Subsequent to the Buffer $\mathrm{pH}$ determination, lime requirement is calculated using the amount of exchangeable (potential) acidity in the soil. Currently, the ESTL does not provide information concerning methods of lowering soil $\mathrm{pH}$.

Results from the above soil tests are interpreted for crop response based on Table 1. The interpretation values are determined from several long-term field calibration studies conducted for various crops and soils in Florida and thus form the basis for lime, nutrient and management recommendations detailed on the soil test report sent to the clients.
The ESTL Soil Test Report will specify the recommended quantities of macronutrients $(\mathrm{N}, \mathrm{P}, \mathrm{K}$, $\mathrm{Ca}$ and $\mathrm{Mg}$ ) to be applied to the soil in order to increase the supply of these nutrients to the levels needed for optimum yield and/or quality for the crops requested. Quantities are reported in either pounds per acre, pounds per 100 linear bed feet, pounds per 1000 square feet, or pounds per 100 square feet, depending on the crop. ${ }^{5}$ The $\mathrm{P}$ and $\mathrm{K}$ recommendations are both reported as the oxide forms $\left(\mathrm{P}_{2} \mathrm{O}_{5}\right.$ and $\left.\mathrm{K}_{2} \mathrm{O}\right)$ in order to comply with current fertilizer-label requirements. Recommended quantities of $\mathrm{N}, \mathrm{Ca}$ and $\mathrm{Mg}$ are reported as the elemental form. The report also will indicate the amount of lime needed, if any, to be added to the soil in order to raise the soil $\mathrm{pH}$ to that of the Target $\mathrm{pH}$ of the crop requested.

It should be noted that recommendations for $\mathrm{N}$ are not based on soil testing. The ESTL does not currently test for $\mathrm{N}$ in soil due to lack of a meaningful soil test method through which $\mathrm{N}$ availability to meet plant needs can be predicted. The recommendations for $\mathrm{N}$ shown on the soil test report form are instead based on research studies that measured the response of the indicated crop to various levels of applied $\mathrm{N}$ fertilizers. The results of these studies are then used to determine the correct amount of $\mathrm{N}$ needed for optimum crop response. If part of the soil $\mathrm{N}$ requirements will be met through nutrient release from organic sources such as crop residue or organic soil amendments, the $\mathrm{N}$ fertilizer recommendation should be lowered appropriately by estimating the $\mathrm{N}$ availability of the amendment material.

An integral part of the recommendations are the footnotes. The footnotes included in the report elaborate on many aspects of fertilization and cultural management for the specified crop(s). It is strongly recommended that the producers consider the information contained in these footnotes when making management decisions for efficient fertilizer use.

The ESTL also offers a micronutrient test for Mehlich-1 extractable $\mathrm{Cu}, \mathrm{Mn}$, and $\mathrm{Zn}$. The primary value of the micronutrient soil test is to determine if adequate levels of micronutrients already exist in the soil. The interpretation of the soil micronutrient test 
Table 1. Current interpretation for Mehlich-1 soil test results for agronomic and vegetable crops.

\begin{tabular}{cccccc|}
\hline \hline & Very Low & Low & Medium & High & $\begin{array}{c}\text { Very } \\
\text { High }\end{array}$ \\
& & & & & \\
\hline $\mathrm{P}$ & $<10$ & $10-15$ & $16-30$ & $31-60$ & $>60$ \\
$\mathrm{~K}$ & $<20$ & $20-35$ & $36-60$ & $61-125$ & $>125$ \\
$\mathrm{Mg}$ & -- & $<15$ & $15-30$ & $>30$ & \\
\hline \hline
\end{tabular}

results and proper micronutrient fertilization is included with the report. Micronutrient fertilizers should be used with discretion since it is possible to build up toxic levels of these elements in a soil. Use of the "shotgun" approach (i.e., addition of micronutrients as "insurance") should be avoided. It should also be noted that pesticide formulations frequently contain one or more of these micronutrients. Therefore if pesticides are applied, additional application of micronutrient fertilizer is often unnecessary.

\section{Tests to Choose From}

\section{Landscape, Lawn, and Vegetable Garden Test $^{13}$}

The UF/IFAS ESTL offers two soil testing options for the homeowner or home gardener. The first soil test option is for soil $\mathrm{pH}$ and lime requirement determination. No other nutrient analysis or fertilizer recommendation is provided under this option. The measured soil $\mathrm{pH}$ is compared to the Target $\mathrm{pH}$ for the crop specified by the homeowner or gardener and a lime requirement, if any, is determined using the Adams-Evans Buffer $\mathrm{pH}$ Index. Both the soil $\mathrm{pH}$ and the recommended lime application rate for the specified crop are included in the soil test report. General fertilizer recommendations for landscape, lawns, and vegetable gardens can then be found in a variety of IFAS extension publications by visiting http://edis.ifas.ufl.edu or the local County Extension Agency. It should be noted that general recommendations do not account for nutrients supplied to the plant from sources already within the soil. Instead, all nutrition is assumed to come only from the fertilizer added to the soil.
The second option includes tests for soil $\mathrm{pH}$ and lime requirement alongwith macronutrients (Mehlich-1 extractable $\mathrm{P}, \mathrm{K}, \mathrm{Ca}$ and $\mathrm{Mg}$ ). This information is then used to calculate specific lime and fertilizer recommendations for the crop of interest and is included in the soil test report along with the appropriate footnotes. This allows the homeowner or gardener to develop their fertilization program according to the specific fertilizer needs of the crop they are growing. Recommendations are made for a variety of crops including landscaping plants, ornamentals, vegetable gardens, and lawn grasses (bahia, bermuda, centipede, St Augustine, etc) and are reported as either pounds of nutrient per 100 square feet or per 1000 square feet.

\section{Pine Nursery Soil Test ${ }^{17}$}

Soil samples from a pine nursery should be obtained from the 0- to 6-soil depth only, and will be analyzed for soil $\mathrm{pH}$, organic matter, and Mehlich-1 extractable $\mathrm{P}, \mathrm{K}, \mathrm{Ca}$, and $\mathrm{Mg}$.

\section{Container Media Test ${ }^{15}$}

The ESTL Container Media Test is used to measure the levels of water-soluble nutrients in soilless media (e.g., mixtures of materials such as perlite, expanded plastics, vermiculite, peat, pine bark, wood shavings, compost, and sand). Analyses include $\mathrm{pH}$, electrical conductivity, nitrate- $\mathrm{N}, \mathrm{P}, \mathrm{K}$, $\mathrm{Ca}$, and $\mathrm{Mg}$, all of which are measured in a saturated water extract from the soilless media. This test is recommended as a diagnostic tool for fertilizer management in commercial container-plant production as a means of monitoring nutrients in the media throughout the growing season. The test report also provides the fact sheet ${ }^{12}$ that assist in the interpretation of the results. Test interpretations are meaningful only in commercial nursery situations. 
Unlike the other soil tests offered by the ESTL, container-media samples should NOT be dried prior to their delivery to the laboratory. Drying these types of media can adversely affect the results of the test by changing the amounts of nutrients extracted from the media.

\section{Plant Tissue Test ${ }^{18}$}

In addition to soil testing, the ESTL also offers a Plant Tissue Test. This test is offered specifically to commercial growers of blueberries and pecans and to IFAS county extension faculty for use as a diagnostic tool. Test results from samples submitted by commercial growers are forwarded to an Extension blueberry or pecan specialist, who evaluates the data and provides a report to the grower. Results from diagnostic samples are provided to the submitting agent or specialist only. The agent/specialist is responsible for interpreting the data for the client.

\section{Water Test ${ }^{16}$}

The ESTL offers testing of both household and other water supplies used for irrigation/microirrigation for mineral determinations only. All health-related and drinking water quality inquiries should be directed to the nearest county Health Department. Additionally, questions concerning municipal water supplies should be referred to the Department of Health and Rehabilitative Services as that agency is responsible for monitoring the quality of municipal water sources.

The ESTL Water Test Report includes values for $\mathrm{pH}, \mathrm{Ca}, \mathrm{Mg}, \mathrm{Fe}, \mathrm{Mn}, \mathrm{Na}, \mathrm{Cl}$, hardness, total carbonates, and electrical conductivity. The irrigation water test includes all of the above, as well as a test for suspended solids. The report provides tables assisting with the interpretation of results. ${ }^{3,4}$

In Florida, many irrigation-water sources originate from limestone aquifers, resulting in high-pH waters. Crops that are $\mathrm{pH}$-sensitive, such as blueberries or pine seedlings, may benefit considerably by pretreating such water with acid to destroy carbonates and concurrently lower the $\mathrm{pH} .{ }^{10}$ Results from the total carbonates test can be used to determine the amount of acid required to reduce this high-pH condition.

\section{Sample Submission}

\section{How to Submit Samples to the ESTL}

A Sample Submission Form and full payment for the requested services should accompany the samples. Sample Submission Forms can be printed directly from the ESTL website (http://soilslab.ifas.ufl.edu) or can be picked up from the local county Extension office. Samples may be sent directly to the ESTL via the U.S. Postal Service or express delivery companies. Instructions for collection of a representative sample, proper sample amount, mailing address and other vital information needed for proper sample processing are printed on the forms (described below). Mailing boxes for shipping samples to the ESTL are also available from the county Extension office. Samples may also be personally delivered directly to the laboratory in order to avoid shipping/mailing delays.

Sample analysis generally requires an average of five working days from the time the sample is received at the ESTL. Results are e-mailed or mailed directly to the address provided on the submission form. Additionally, a copy of these results is sent to the county Extension office. All county Extension offices have the capacity to receive test results via electronic mail. Clients are encouraged to contact their county Extension office when seeking further assistance. Clients may also request to receive a copy of their results via fax.

\section{Sample Submission}

Relevant sample submission form(s) needs to be filled out completely and accompany all samples submitted for testing. The following forms correspond to the tests and testing options described above and can be downloaded and printed by the clients by from the following links. These and other information can also be accessed by visiting the ESTL website (http://soilslab.ifas.ufl.edu). The forms are also available from the nearest county Extension office.

Producer Soil Test Information Sheet (Fact Sheet SL-135). This form has been designed for use by commercial producers. The information sheet is 
self-explanatory and provides pertinent information for samples submitted to the ESTL.

\section{Landscape and Vegetable Garden Soil Test} Information Form (Fact Sheet SL-136). Both private and commercial clients fertilizing plants in the landscape, primarily home horticulture, should use this form.

Container Media Test Information Form (Fact Sheet SL-134). This form is designed for use by commercial growers using soilless media for container-plant production.

Pine Nursery Soil Test Information Sheet (Fact Sheet SL-132). Commercial operators of pine plantations and pine nurseries should use this form.

Plant Tissue Analysis Information Sheet (Fact Sheet SL-131). This form is used for submission of plant tissue samples. Only blueberry and pecan leaf samples are tested under this option. All other plant tissue samples must be sent with the consent of an extension agent or state specialist. The agent or specialist assumes the responsibility for interpretation of the plant tissue report.

Water Test Information Sheet (Fact Sheet SL-133). This form should be used for analysis of irrigation water or household well water (not municipal or drinking water).

Other supplies related to testing and sampling that can also be obtained at the county extension office include:

1) Soil sample bags.

2) A self-addressed cardboard mailer.

\section{Sample Preparation}

\section{Soil Samples}

Soil samples should be air-dried before shipment to the ESTL. Drying is best accomplished by spreading a thin layer of soil on clean wrapping paper or newspaper and placing it in a dry shaded area for at least 24 hours. Drying samples in direct sunlight or using a household oven is NOT recommended.

\section{Container Media Samples}

Container media samples should NOT be dried before shipment to the ESTL. Drying media samples will adversely affect the test results decreasing the usefulness of the test.

\section{Plant Samples}

The quality of the tissue samples submitted for analysis is of importance in ensuring proper processing and interpretation of the results. Tissue samples should not be contaminated with soil or sprays. If the tissue is dusty or contaminated, the sample should be gently washed with flowing distilled water and allowed to dry overnight prior to shipping. Do not sample diseased or damaged plant materials. Consult the local Extension agent to determine the proper plant part and the proper time to sample. Always place the tissue samples in paper bags only. Plastic bags are NOT recommended.

\section{Water Samples}

The container in which a water sample is sent to the ESTL can influence results greatly. For example, residual soap from a plastic dish soap container will contaminate the water sample. The container should be clean to avoid contamination of the sample. The sample should be taken several minutes after the water source has been flowing from the spigot or irrigation pump. The container should be flushed thoroughly several times with the flowing water. The container should be filled completely with no airspace at the container top. Entrapped air in the container may affect well-water samples due to shifts in carbon dioxide, potentially affecting its $\mathrm{pH}$.

\section{Analytical Procedures for Soil}

\section{Soil Scooping Technique ${ }^{8}$}

Soil scooping technique is employed to draw an estimated weight of soil sample for testing from the soil sample submitted/prepared. The soil-scooping technique requires practice, despite its unsophisticated appearance. The technique depends upon uniform actions by the technician from sample to sample to produce consistent packing of soil into the scoop. To check scooping consistency, repeatedly scoop soil from one sample and check the weight of 
each scoop. If the procedure is being carried out properly, the weights should be uniform. The average weights for various scoop volumes are given in Table 2. Scoop weights will vary from soil to soil depending on differences in soil texture.

\section{Procedure}

1. Dip the scoop into the center of the soil sample and fill the scoop with a twisting motion so that extra soil is mounded above the rim of the scoop. Do not press the scoop or force the soil against the side of the container. ${ }^{8}$

2. Strike the handle near the scoop three times with a plastic rod to settle soil particles.

3. Level the scoop with the plastic rod. Strike off all excess soil above the rim of the scoop in a single stroke so that the soil is not compacted into the scoop.

\section{Procedure}

1. Standardize $\mathrm{pH}$ meter according to manufacturers directions.

2. Scoop $20-\mathrm{cm}^{3}$ of soil and pour into a $90-\mathrm{mL}$ (3-oz) plastic cup.

3. Add $40 \mathrm{~mL}$ of pure water to each cup using an automatic pipette. Stir with a glass rod and let the sample stand for $30 \mathrm{~min}$, but not more than 2 hours. Stir sample again just prior to analysis.

4. Continue stirring sample and measure soil $\mathrm{pH}$.

5. Record $\mathrm{pH}$ to the nearest $0.1 \mathrm{pH}$ unit (XX.X).

\section{Adams-Evans Buffer $\mathrm{pH}^{\mathbf{1}}$}

This procedure uses a $15-\mathrm{cm}^{3}$ soil scoop and 30 $\mathrm{mL}$ of Adams-Evans Buffer solution for a soil to

Table 2. Applications for scoops used at the Extension Soil Testing Laboratory.

\begin{tabular}{|c|c|c||}
\hline \hline $\begin{array}{c}\text { Scoop Volume } \\
\left(\mathbf{c m}^{\mathbf{3}}\right)\end{array}$ & $\begin{array}{c}\text { Approx. soil } \\
\text { weight } \mathbf{( g )}\end{array}$ & Application \\
\hline 4 & 5 & Mehlich-1 extraction \\
\hline 15 & 20 & Adams-Evans Buffer pH \\
\hline 20 & 25 & Soil pH and electrical conductivity \\
\hline Note: Soil for the AB-DTPA extraction procedure is weighed only. \\
\hline
\end{tabular}

\section{Soil $\mathrm{pH}(1: 2 \mathrm{v} / \mathrm{v})$}

This procedure uses a $20-\mathrm{cm}^{3}$ soil scoop and 40 $\mathrm{mL}$ of pure water to obtain a 1:2 soil-to-water ratio. Sample pH may be affected by contaminated water, by microbial activity or by changes in solution chemistry if samples are allowed to sit longer than recommended prior to ananlyisis. Other common errors associated with this method include improper scooping technique and improper electrode use. The $\mathrm{pH}$ meter should be calibrated on a daily basis using commercially available buffer solutions. Fresh aliquots of buffer solution must be used each day.

\section{Standard Solutions}

Obtain commercially available standard buffer solutions of $\mathrm{pH} 4.00,7.00$, and 10.00. solution ratio of 1:2. Errors associated with this method include improper standardization of the Adams-Evans buffer solution, improper use of the electrode, and delays in analysis beyond the recommended equilibration period.

\section{Reagents}

Reagents used in this procedure are listed in Table 3.

\section{Solutions}

The Adams-Evans Buffer solution is prepared as follows:

1. Weigh $180 \mathrm{~g}$ of the p-Nitrophenol into a 6-L Erlenmeyer flask containing about $4 \mathrm{~L}$ of pure water. Add $135 \mathrm{~g}$ of the Boric Acid and dissolve. Use low heat to dissolve, if necessary. 
Table 3. List of reagents used in Adams-Evans Buffer pH procedure.

\begin{tabular}{||l|l|l||}
\hline \hline Name & Formula & F.W. $^{*}$ \\
\hline$p$-Nitrophenol & $\mathrm{NO}_{2} \mathrm{C}_{6} \mathrm{H}_{4} \mathrm{OH}$ & 139.11 \\
\hline Boric Acid & $\mathrm{H}_{3} \mathrm{BO}_{3}$ & 61.8 \\
\hline Potassium Hydroxide & $\mathrm{KOH}$ & 56.1 \\
\hline Potassium Chloride & $\mathrm{KCl}$ & 74.6 \\
\hline * Formula weight in grams. \\
\hline \hline
\end{tabular}

2. Dissolve $95 \mathrm{~g}$ of the Potassium Hydroxide in approximately $200 \mathrm{~mL}$ of pure water contained in a $500-\mathrm{mL}$ beaker.

3. Using a $20-\mathrm{L}$ carboy calibrated at $18-\mathrm{L}$ volume, add $6 \mathrm{~L}$ of pure water. Weigh $666 \mathrm{~g}$ of the Potassium Chloride and transfer to the carboy.

4. Combine all solutions by quantitatively transferring the p-Nitrophenol/Boric Acid solution, followed by the Potassium Hydroxide solution, to the carboy containing the Potassium Chloride solution. Bring to 18-L final volume with pure water. Adjust the solution $\mathrm{pH}$ to 8.00 0.02 with small amounts of Potassium Hydroxide (for raising $\mathrm{pH}$ ) or Hydrochloric Acid (for lowering $\mathrm{pH}$ ), as needed. Let stand overnight and check $\mathrm{pH}$.

Alternately, a commercially prepared Adams-Evans buffer solution can be purchased and prepared as per the manufactures instructions.

\section{Procedure}

1. Standardize the $\mathrm{pH}$ meter according to the manufacturers directions.

2. Measure the $\mathrm{pH}$ of the Adams-Evans Buffer Solution to insure that the solution reads 8.00 0.02 .

3. Scoop a $15-\mathrm{cm}^{3}$ volume of soil into a $50-\mathrm{mL}$ beaker.

4. Add $30 \mathrm{~mL}$ of the buffer solution using an automatic pipette.

5. Stir for 4 min on a mechanical stirrer. Timing of this test is critical. The reaction starts when the buffer solution is added to the sample.
6. Immediately after stirring, measure the solution $\mathrm{pH}$. Excessive delays will result in low bias in the buffer-pH readings.

7. Record $\mathrm{pH}$ to the nearest $0.01 \mathrm{pH}$ unit (XX.XX).

\section{Mehlich-1 Extractable P, K, Ca, Mg, Cu, Mn, and $\mathrm{Zn}^{21}$}

This procedure uses a $4-\mathrm{cm}^{3} \mathrm{scoop}$ (approximately $5 \mathrm{~g}$ of mineral soil) and $20 \mathrm{~mL}$ of the Mehlich-1 extraction solution to provide a soil to solution ratio of 1:4. Once the extraction is complete, the sample is filtered through Whatman 42 filter paper or its equivalent. The filtered solution should be analyzed as soon as possible following the extraction procedure. If refrigeration is not available, the sample must be analyzed the same day as it is extracted. With refrigeration, samples should be analyzed within five days. Common errors associated with this method include mistakes in sample shake time, delayed filtration, and reagent, filter paper or cup contamination.

\section{Reagents}

A list of reagents is found in Table 4.

Table 4. List of reagents used in Mehlich-1 Extractable $\mathrm{P}, \mathrm{K}$, $\mathrm{Ca}, \mathrm{Mg}, \mathrm{Cu}, \mathrm{Mn}$, and $\mathrm{Zn}$ procedure.

\begin{tabular}{||l|l|l||}
\hline \hline Name & Formula & Conc. \\
\hline Sulfuric Acid & $\mathrm{H}_{2} \mathrm{SO}_{4}$ & $18 \mathrm{M}$ \\
Hydrochloric Acid & $\mathrm{HCl}$ & $12.1 \mathrm{M}$ \\
\hline \hline
\end{tabular}

\section{Solutions}

Mehlich-1 Extracting Solution $\left(0.0125 \mathrm{M} \mathrm{H}_{2} \mathrm{SO}_{4}\right.$ and $0.05 \mathrm{M} \mathrm{HCl}$ )

Pour approximately $16 \mathrm{~L}$ of pure water into a 20-L plastic carboy. Slowly add $13.9 \mathrm{~mL}$ of concentrated Sulfuric acid and $83 \mathrm{~mL}$ of concentrated Hydrochloric Acid. Dilute to 20-L final volume with pure water and mix.

\section{Procedure}

1. Scoop $4 \mathrm{~cm}^{3}$ of mineral soil and transfer into a 50 -mL extracting bottle. 
2. Dispense $20 \mathrm{~mL}$ of Mehlich- 1 extracting solution into each extracting bottle using an automatic pipette.

3. Shake each sample for $5 \mathrm{~min}$ on a reciprocating shaker and then filter through filter paper $(11 \mathrm{~cm}$ Roger's Custom Lab 620, Whatman No. 42 or equivalent) into a plastic cup.

4. Transfer the filtrate to an appropriate vial for analysis. If samples are not to be analyzed immediately, they should be capped or otherwise covered. Sample solutions are stable for 5 days, if refrigerated.

5. The filtrate may be analyzed for nutrients using either ICP (Inductively Coupled Plasma Spectrometer, EPA Method 200.7) or AAS (Atomic Absorption/flame emission Spectrophotometer, EPA Method 200.0) in combination with colorimetric analysis for phosphorus determination (EPA Method 365.2).

6. Instrument readings are recorded in $\mathrm{mg} \mathrm{L}^{-1}$ solution concentration. Final results are reported in $\mathrm{mg} \mathrm{kg}^{-1}$-dry weight (ppm) calculated as follows:

$$
\frac{\mathrm{mg}}{\mathrm{L}} \times \frac{1 \mathrm{~L}}{1000 \mathrm{~mL}} \times \frac{\mathrm{mL} \text { sol'n }}{\mathrm{g} \text { soil }} \times \frac{1000 \mathrm{~g}}{1 \mathrm{~kg}}=\frac{\mathrm{mg}}{\mathrm{kg}}
$$

Soil Organic Matter ${ }^{2}$

\section{A. Walkley-Black Method ${ }^{19}$}

The Walkley Black (WB) method used for determining Soil Organic Matter (SOM) involves a known volume of acidic dichromate solution reacting with an aliquot of soil in order to oxidize the SOM. The oxidation step is then followed by titration of the excess dichromate solution with ferrous sulfate. The SOM is calculated using the difference between the total volume of dichromate added and the volume titrated after reaction. Problems associated with this procedure include excessive organic matter in the soil (the limit for this procedure is approximately 6\%) and difficult end point determination (dark-colored soil solution). The use of a lighted stir plate can be of assistance in the end-point determination. The WB procedure also results in production of chromate, which is categorized as a hazardous chemical. Studies are currently ongoing to develop an alternative method to WB to avoid production any hazardous waste.

\section{Reagents}

Reagents used in this procedure are listed in Table 5 .

\section{Solutions}

\subsection{Potassium dichromate}

Dissolve $98.08 \mathrm{~g}$ of oven-dry/desiccated Potassium dichromate in approximately $1500 \mathrm{~mL}$ of pure water and dilute to $2 \mathrm{~L}$. After preparation of this solution, transfer to a clean glass bottle for use with a repipetter. Do not mix old Potassium dichromate solution with the new solution.

\subsection{Ferrous Sulfate}

Dissolve $556.04 \mathrm{~g}$ of Ferrous Sulfate in approximately $1500 \mathrm{~mL}$ of pure water. Carefully add $30 \mathrm{~mL}$ of concentrated Sulfuric Acid, mix, cool, and dilute to $2 \mathrm{~L}$. After preparation, this solution may be transferred to a clean 8-L plastic carboy. Do not mix old Ferrous Sulfate solution with the new solution. The tubing, stopcock, and attachments to the burette should be rinsed three times with new Ferrous Sulfate solution before titrating any blanks or samples.

Prepare a new solution every 30 days.

\section{Procedure}

1. Weigh $1.0 \mathrm{~g}$ of mineral soil into a $250-\mathrm{mL}$ wide mouth graduated Erlenmeyer flask.

2. Titrate two blank samples (no soil) before proceeding with any unknown samples in order to standardize the Ferrous Sulfate solution. If the difference between the two blanks is not within $0.2 \mathrm{~mL}$ of Ferrous Sulfate solution, clean the burette and associated tubing. Reanalyze two more blanks to determine if the problem has been eliminated.

3. Pipet $10.0 \mathrm{~mL}$ of the Potassium dichromate solution into each flask containing unknown soil and mix by carefully rotating the flask to wet all of the soil. 
Table 5. List of reagents used in the Walkley-Black Method.

\begin{tabular}{||l|l|l||}
\hline \hline Name & Formula & F.W./Conc. ${ }^{*}$ \\
\hline Potassium dichromate & $\mathrm{K}_{2} \mathrm{Cr}_{2} \mathrm{O}_{7}$ & 294.19 \\
\hline Ferrous Sulfate & $\mathrm{FeSO}_{4} \cdot 7 \mathrm{H}_{2} \mathrm{O}$ & 278.02 \\
\hline Sulfuric Acid & $\mathrm{H}_{2} \mathrm{SO}_{4}$ & $18 \mathrm{M}$ \\
\cline { 2 - 3 } & \multicolumn{2}{|l||}{ 10-Phenanthroline Ferrous Sulfate complex } \\
\hline * Formula weights in grams or concentration in Molarity. \\
\hline
\end{tabular}

4. Under a fume hood, carefully add $20 \mathrm{~mL}$ of concentrated Sulfuric Acid to each flask and mix gently.

5. Allow flasks to stand for 5 min under the fume hood.

6. Add pure water to each flask such that the final volume is approximately $125-\mathrm{mL}$. Mix by swirling gently.

7. Add 5 or 6 drops of Phenanthroline complex and immediately titrate with the Ferrous Sulfate solution. As the titration proceeds, the solution will take on a green color that will change abruptly to reddish-brown when the endpoint of the titration is reached.

8. Record each volumetric reading to the nearest X.X mL.

9. The $\% \mathrm{OM}$ is calculated as follows:

$(1-\mathrm{S} / \mathrm{B}) \times 10 \times 0.68=$ organic matter $(\%)$ of sample

where:

$\mathrm{S}=$ Volume of Ferrous Sulfate solution required to titrate the sample, in $\mathrm{mL}$.

$\mathrm{B}=$ Average Volume of Ferrous Sulfate solution required to titrate the two blanks, in $\mathrm{mL}$.

$10=$ conversion factor for units.

$0.68=\mathrm{a}$ factor derived from the conversion of $\%$ organic carbon to \% organic matter (1.724), the fraction of Organic Carbon oxidized to $\mathrm{CO}_{2}(0.76)$ and the milliequivalent weight of carbon $(0.003 \mathrm{~g})$.

\section{B. Loss-on-Ignition Method ${ }^{11}$}

The Loss-on-Ignition (LOI) organic matter determination is used for analyzing soil samples in which the organic matter content is greater than $6 \%$. This procedure involves exposing the soil sample to high temperatures in an oxygen atmosphere in order to convert any organic carbon compounds to carbon dioxide, which is then lost to the atmosphere. The difference between the soil dry weight and the weight of the sample after ignition is then used to calculate the amount of organic matter in the sample. This procedure has been reported to be consistent with even lower SOM levels $(<6 \%)$ such as sandy soils in Florida. Studies are on-going to determine the suitability and for possible replacement method for WB procedure.

\section{Procedure}

1. Label and accurately weigh (to 4 decimal places) an oven dried $50 \mathrm{~mL}$ Pyrex beaker.

2. Add approximately 5-6 $\mathrm{g}$ of soil to the beaker.

3. Place sample in the oven at a constant temperature of $105^{\circ} \mathrm{C}$ and allow sample to dry for a minimum of $2 \mathrm{hrs}$.

4. Remove sample from the oven at the end of two hours and place immediately into a dessicator to cool. Allow sample to cool to room temperature (approximately 30 minutes) and then accurately weigh sample and beaker.

5. After weighing, place sample into a muffle furnace and heat at $350^{\circ} \mathrm{C}$ for a minimum of 2 
hours. Do not exceed this temperature as $\mathrm{CaCO}_{3}$ may be converted to $\mathrm{CO}_{2}$ and cause erroneous results.

6. At the end of the heating period, allow samples to cool slightly and then transfer immediately to a dessicator. Allow samples to cool to room temperature in the dessicator.

7. After samples reach room temperature, remove from the dessicator and accurately weigh sample and beaker.

8. The $\% \mathrm{OM}$ is calculated as follows:

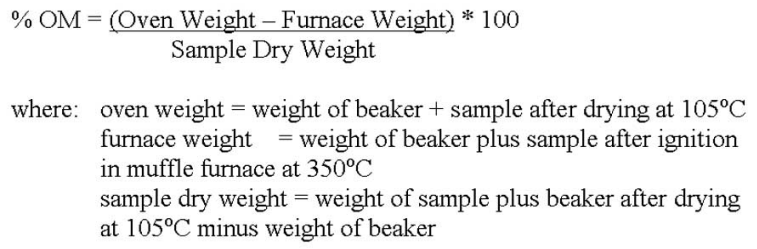

\section{Electrical Conductivity (1:2 Soil:Water)}

The ESTL offers a test for soil Electrical Conductivity (EC) by which a value for the "Soluble Salts" in the soil content can be estimated. In this test, $20 \mathrm{~cm}^{3}$ of a mineral soil are mixed with $40 \mathrm{~mL}$ of pure water resulting in a soil to water ratio of 1:2. The resultant suspension is allowed to equilibrate for 4 hours in order to allow slowly-soluble constituents to approach solution equilibrium. The suspension is then filtered and the electrical conductivity is immediately determined. Sources of error include improper instrument calibration and incorrect equilibration times.

\section{Standards}

A solution of $0.005 \mathrm{M} \mathrm{KCl}$ has an electrical conductivity of 720 deciSiemens per meter $(\mathrm{dS} / \mathrm{m})$ at $25^{\circ} \mathrm{C}$. Alternately, a commercially available NIST traceable reference solution of the appropriate concentration and conductivity may be used.

\section{Procedure}

1. Weigh $20 \mathrm{~g}$ of soil and transfer to a plastic 90-mL (3-oz.) cup.
2. Add $40 \mathrm{~mL}$ of pure water to each cup. Stir and allow the suspension to stand for 4 hours.

3. At the end of 4 hours, stir the suspension to create slurry. Immediately filter through an 11 cm filter paper (Roger's Custom Lab 620, Whatman No. 42 or equivalent). Collect the filtrate in a $90-\mathrm{mL}$ (3-oz.) plastic cup.

4. Using the reference standard, calibrate the Electrical Conductivity Meter according to manufacturers directions. Measure the EC of the solution and report results to one decimal place in $\mathrm{dS} / \mathrm{m}$.

While the ESTL reports all electrical conductivity measurements in $\mathrm{dS} / \mathrm{m}$, many clients are accustomed to values given in ppm "soluble salts". The calculation to convert EC to soluble salts is given below along with the formula for conversion of EC to salt index. There are many inaccurate assumptions included in these conversions and clients are encouraged to adapt to the more precise and widely-accepted terminology of EC in $\mathrm{dS} / \mathrm{m}$.

$\mathrm{EC}$ in $\mathrm{dS} / \mathrm{cm} \times 700=$ soluble salts in $\mathrm{ppm}$

Salt index $=E C($ as direct 2:1 reading $)$ x 8

\section{Analytical Procedures for Container Media}

\section{Water-Extractable $\mathrm{P}, \mathrm{K}, \mathrm{Ca}, \mathrm{Mg}, \mathrm{NO}_{3}-\mathrm{N}, \mathrm{pH}$, and Electrical Conductivity}

The entire sample (or that portion of the sample that nearly fills a $600-\mathrm{mL}$ plastic beaker) is used for this diagnostic test. ${ }^{15}$ De-ionized distilled water is added to the sample to the point of saturation. The sample is then filtered under vacuum and the filtrate is analyzed. Under- or over-estimating the point of sample saturation will introduce some error. If possible, the analysis of the filtrate should be completed on the same day that the extract is prepared. If unable to complete the analysis on the same day, the sample may be refrigerated but analysis must be completed within 48 hours or the sample must be re-extracted.

\section{Extraction Procedure}


1. Place the entire sample (or a representative sample aliquot) into a $600-\mathrm{mL}$ plastic beaker and conservatively add pure water to the point of complete saturation. At this point, the surface of the mix should glisten, but no water should puddle on the surface. Mix well with a spatula, and let stand for 2 hours.

2. Place a 9-cm, Whatman No.1 filter paper into a large Buchner funnel. Wet the filter paper with approximately $2 \mathrm{~mL}$ of pure water and transfer the saturated media onto the filter.

3. Place the funnel under a vacuum and leave until sufficient solution is extracted from media to complete the necessary tests. Transfer the filtrate to an appropriate container for analysis.

\section{pH}

Standardize the $\mathrm{pH}$ meter according to manufacturers directions and then determine the $\mathrm{pH}$ of an aliquot of the filtrate. Results are reported to one decimal place.

\section{EC}

Standardize the EC meter according to manufacturer's directions and then determine the electrical conductivity of an aliquot of the filtrate. Report results to one decimal place in $\mathrm{dS} / \mathrm{m}$.

\section{$\mathrm{NO}_{3}-\mathrm{N}$}

The ESTL uses semi-automated colorimetric analysis (EPA Method 353.2) to determine $\mathrm{NO}_{3}-\mathrm{N}$ in the media extract. The instrument (Technicon II Auto-Analyzer or equivalent) is set up and calibrated as per manufacturers directions. Instrument results are reported to one decimal place as $\mathrm{mg} \mathrm{L}^{-1} \mathrm{NO}_{3}-\mathrm{N}$.

\section{Water-Extractable P, K, Ca, Mg}

1. The filtrate may be analyzed for all other nutrients using either ICP or AAS in combination with colorimetric analysis for phosphorus determination.

2. Results for $\mathrm{P}, \mathrm{K}, \mathrm{Ca}$, and $\mathrm{Mg}$ are reported in $\mathrm{mg}$ $\mathrm{L}^{-1}$ (ppm).

\section{Analytical Procedures for Calcareous Soils}

\section{Ammonium Bicarbonate-DTPA (AB-DTPA) Extractable $\mathbf{P}$}

The AB-DTPA extractant works well on soils with high and neutral $\mathrm{pH} .{ }^{6,20}$ It is being calibrated for the marl and Rockdale soils of southern Florida. Previous studies in Florida have shown that this procedure can be interpreted only for P test results. Therefore, results for other nutrients are included in the report. It is not suitable for determination of $\mathrm{Ca}$ or $\mathrm{Mg}$. This extraction procedure is used only on soils that have a $\mathrm{pH}$ of 7.4 and above.

\section{Solutions}

\section{AB-DTPA Extracting Solution}

Prepare this solution under a fume hood to avoid possible contact with vapors. Add approximately 700 $\mathrm{mL}$ of pure water into a $1-\mathrm{L}$ volumetric flask. Add 0.5 $\mathrm{mL}$ (10 drops) of concentrated Ammonium Hydroxide. Dissolve $1.97 \mathrm{~g}$ of DTPA in this solution. This dissolution may take several hours. After the DTPA has been dissolved, add $79.06 \mathrm{~g}$ of Ammonium Bicarbonate, mix, and dilute to $1 \mathrm{~L}$. Adjust to $\mathrm{pH} 7.6$ using concentrated Hydrochloric Acid (for lowering $\mathrm{pH}$ ) or Ammonium Hydroxide (for raising $\mathrm{pH}$ ). Prepare this solution daily, as it is $\mathrm{pH}$ unstable.

\section{Reagents}

Reagents used in this procedure are listed in Table 6 .

\section{Procedure}

1. Weigh $12.5 \mathrm{~g}$ of soil and place into a $125-\mathrm{mL}$ (4-oz.) wide mouth polypropylene bottle with a screw cap which contains a $2.4-\mathrm{mm}$ (3/32 inch) round hole to release $\mathrm{CO}_{2}$ pressure.

2. Dispense $25 \mathrm{~mL}$ of the AB-DTPA extracting solution in each bottle and secure the cap.

3. Shake for $15 \mathrm{~min}$ on a reciprocating shaker set at approximately 180 reciprocations per minute, and filter through an 11-cm filter paper (Roger's 
Table 6. List of Reagents used in Ammonium Bircarbonate-DTPA (AB-DTPA) Extractable P.

\begin{tabular}{||l|l|l||}
\hline \hline Name & Formula & F.W./Conc. ${ }^{*}$ \\
\hline Ammonium Hydroxide, concentrated & $\mathrm{NH}_{4} \mathrm{OH}$ & $14.8 \mathrm{M}$ \\
\hline DPTA (Baker Cat. E 376-.07) & $\mathrm{C}_{14} \mathrm{H}_{23} \mathrm{~N}_{3} \mathrm{O}_{10}$ & 393.35 \\
\hline Ammonium Bicarbonate & $\mathrm{NH}_{4} \mathrm{HCO}_{3}$ & 79.06 \\
\hline Hydrochloric Acid, concentrated & $\mathrm{HCl}$ & $12.1 \mathrm{M}$ \\
\hline Nitric Acid, concentrated & $\mathrm{HNO}_{3}$ & $15.8 \mathrm{M}$ \\
\hline * Formula weights in grams or concentration in Molarity. \\
\hline \hline
\end{tabular}

Custom Lab 620, Whatman No. 40 or equivalent) into a $90-\mathrm{mL}$ (3-oz) plastic cup.

4. Transfer $10 \mathrm{~mL}$ of each unknown into another 90-mL (3-oz.) plastic cup using an adjustable calibrated macropipetter and a clean tip for each sample.

5. Acidify the solution by adding $1 \mathrm{~mL}$ (20 drops) of concentrated Nitric Acid, swirl carefully, and let sit for 15 to $20 \mathrm{~min}$.

6. Transfer this solution into an appropriate container for analysis and analyze immediately. The filtrate may be analyzed for nutrients using either ICP or AAS in combination with colorimetric analysis for $\mathrm{P}$ determination.

7. If unable to analyze extract immediately, the filtrate may be refrigerated at $4^{\circ} \mathrm{C}$ and held for up to 3 days. 8. Results are reported to one decimal in $\mathrm{mg} \mathrm{L}^{-1}(\mathrm{ppm})$.

\section{Analytical Procedures for Water ${ }^{22}$}

The following procedure lists the various subsections that deal with water analyses. To preclude errors introduced by microbial activity, water samples should be analyzed as soon as possible after sampling. Sample containers should be filled completely with no headspace above the sample surface and should only be opened immediately prior to analysis, since exposure to air can cause changes in the chemical equilibrium of the sample.

\section{pH}

Standardize the $\mathrm{pH}$ meter according to manufacturer's directions and then determine the $\mathrm{pH}$ of an aliquot of the sample. Results are reported to one decimal place.

\section{EC}

Standardize the EC meter according to manufacturer's directions and then determine the electrical conductivity of an aliquot of the sample. Report results to one decimal place in $\mathrm{dS} \mathrm{m}^{-1}$.

\section{Metals}

$\mathrm{Ca}, \mathrm{Mg}, \mathrm{Fe}, \mathrm{Mn}$, and $\mathrm{Na}$ may be analyzed by either ICP (EPA Method 200.7) or AAS (EPA Method 200.0).

\section{$\mathrm{Cl}^{-}$}

The ESTL uses semi-automated colorimetric analysis (EPA Method 325.2) to determine chloride in waters. The instrument (Alpkem Auto-Analyzer) is set up and calibrated as per manufacturers directions. Instrument results are reported to one decimal place as $\mathrm{mg} \mathrm{L}^{-1}$ of $\mathrm{Cl}^{-}$concentration.

\section{Carbonate Equivalent}

A 50-mL aliquot of water sample is titrated against a standardized hydrochloric acid solution to a $\mathrm{pH}$ of 4.0. The volume of acid required is then used to calculate the carbonate and bicarbonate equivalence of the sample. While very low levels of bicarbonates may be present in solution below $\mathrm{pH}$ 7.0, these levels are assumed to pose no problems agriculturally. The volume of acid required to titrate the sample to the desired $\mathrm{pH}$ is assumed to be entirely due to the neutralization of carbonates and bicarbonates. The most common error associated with this method is degradation of the THAM buffer solution. The THAM titrant should be replaced at least 
once every week. Only newly-opened water samples should be analyzed since changes in carbonate and bicarbonate levels can occur upon exposure to the air.

\section{Reagents}

Reagents used in this procedure are listed in Table 7.

Table 7. Reagents used in water analysis procedure.

\begin{tabular}{|l|l|c||}
\hline \hline Name & Formula & F.W/Conc. \\
\hline THAM & $\mathrm{C}_{4} \mathrm{H}_{11} \mathrm{NO}_{3}$ & 121.14 \\
\hline Hydrochloric Acid & $\mathrm{HCl}$ & $12.1 \mathrm{M}$ \\
\hline $\begin{array}{l}\text { * Formula weight in grams or concentration in } \\
\text { Molarity. }\end{array}$ \\
\hline
\end{tabular}

\section{Solutions}

\section{THAM 0.020M Titrant}

Place approximately $1.0 \mathrm{~g}$ of THAM into a glass beaker and cover the beaker with a watch glass. Dry at $75^{\circ} \mathrm{C}$ for 15 to $20 \mathrm{~min}$ and cool to room temperature in a desiccator. Accurately weigh $0.4846 \mathrm{~g}$ THAM and transfer it to a $200-\mathrm{mL}$ volumetric flask. Dissolve the THAM by swirling and bring to volume with pure water. Keep this solution refrigerated until needed.

\section{Standardized Hydrochloric Acid}

Using a pipette, measure $5.0 \mathrm{~mL}$ of concentrated Hydrochloric Acid and quantitatively transfer it to a 10-L carboy calibrated at 7-L. Bring the container to a 7-L volume with pure water. This solution should be standardized before use.

Acid Standardization: Pipette $25.0 \mathrm{~mL}$ of the Hydrochloric Acid prepared above into a $100 \mathrm{~mL}$ beaker or Erlenmeyer flask. Titrate to $\mathrm{pH} 7.00$ with the $0.020 \mathrm{M}$ THAM titrant solution. Repeat this procedure to obtain two readings. The difference between the two readings should be no more than 0.3 $\mathrm{mL}$. Use the average of the two readings to calculate the molarity of the Hydrochloric Acid $(\mathrm{HCl})$ according to the following equation:$$
(\mathrm{M} \mathrm{HCl})=[0.020 \mathrm{M} \text { THAM } \mathrm{x}(\mathrm{mL} \text { of THAM })] /
$$
$(\mathrm{mL}$ of $\mathrm{HCl})$
}

where:

$\mathrm{M} \mathrm{HCl}$ is the calculated Molarity (equivalent to normality for Hydrochloric Acid)

$0.020 \mathrm{M}$ THAM is the Molarity of $0.4846 \mathrm{~g}$ of THAM

mL of THAM is the quantity of THAM needed to reach a final $\mathrm{pH}$ of 7.0

$\mathrm{mL}$ of $\mathrm{HCl}$ is the original volume of Hydrochloric Acid used in the titration process

Record the calculated Molarity to the nearest 0.001 and label the carboy accordingly. If properly prepared and standardized, the molarity of the acid should be within the range of 0.005 to $0.015 \mathrm{M}$. This solution should be restandardized every month.

\section{Procedure}

1. Calibrate the $\mathrm{pH}$ meter according to manufacturers instructions.

2. Pipette $50.0 \mathrm{~mL}$ of the water sample into a 100-mL beaker.

3. Read the $\mathrm{pH}$ of the sample.

4. If the $\mathrm{pH}$ is greater than 7.0, proceed with the titration of the sample.

5. Titrate to $\mathrm{pH}=4.00+/-0.05$ with the standardized Hydrochloric Acid solution. The sample should be stirred during the titration process.

6. Record the volume of Hydrochloric Acid solution used to titrate the sample, to the nearest $0.1 \mathrm{~mL}$. The concentration of total carbonate and bicarbonate, in $\mathrm{m} \mathrm{L}^{-1}$ in the sample is calculated as follows: $\mathrm{L}^{-1}$

$(\mathrm{M} \mathrm{HCl}) \times(\mathrm{mL}$ of $\mathrm{HCl}) \times 1000 / 50.0 \mathrm{~mL}=\mathrm{mg}$

\section{Suspended Solids}

A $100-\mathrm{mL}$ aliquot of the water sample is filtered through a pre-weighed $0.45 \mu$ filter in order to recover all suspended particles (particles smaller than $0.45 \mu$ are by defintion considered dissolved). The 
most common error associated with this method is improper sampling technique. This is especially true for samples containing heavy particles such as sand that may fall out of suspension quickly, making it difficult to accurately obtain the necessary sample aliquot for the analysis.

\section{Procedure}

1. Number each filter using a pencil. Dry for 2 hours at $105^{\circ} \mathrm{C}$. Allow filters to cool in a dessicator.

2. Accurately weigh each filter disk and record the weight to the fourth decimal place (i.e., XX.XXXX g).

3. Shake the original sample vigorously to bring all particles into suspension.

4. Using a graduated cylinder, quantitatively transfer $100 \mathrm{~mL}$ of the sample and filter it through one of the pre-weighed and numbered filters using a micropore filter assembly placed under vacuum.

5. Dry the filter at $105 \mathrm{C}$ for a minimum of 2 hours (to constant weight). Cool in a dessicator and reweigh, recording the weight in the same manner as used above.

6. Calculate the suspended solids in $\mathrm{mg} \mathrm{L}^{-1}$ as follows:

Suspended solids $\left(\mathrm{mg} \mathrm{L}^{-1}\right)=[$ Final weight $(\mathrm{g})$ Initial weight $(\mathrm{g})] / 100 \mathrm{~mL}$ subsample x $1000 \mathrm{mg} \mathrm{x}$ $1000 \mathrm{~mL}$

\section{Analytical Procedures for Plants}

\section{Digestion Procedure for the Determination of $\mathrm{Ca}, \mathrm{Mg}, \mathrm{P}, \mathrm{K}, \mathrm{Na}, \mathrm{Mn}, \mathrm{Cu}, \mathrm{Fe}, \mathrm{Zn}$, and $\mathrm{B}$ in Plant Tissue}

This digestion procedure has been developed with a sufficiently large dilution factor to allow accurate determination of macronutrients and secondary nutrients that are often in relatively high concentrations within the plant. This procedure may not be suitable for certain micronutrient or heavy metal analyses because of the selected dilution factor.
If the expected micronutrient concentration in the plant is less than $5 \mathrm{mg} \mathrm{kg}^{-1}$, the element may be diluted below the detection limit of the method. Selection of muffle furnace temperature and its control directly affect the analytical results of this process. ${ }^{7}$ The use of borosilicate glassware can be a source of B and Si contamination.

\section{Reagents}

Reagents used in this procedure are listed in Table 8 .

Table 8. Reagents used in digestion procedure.

\begin{tabular}{||l|l|l||}
\hline \hline Name & Formula & Conc. $^{*}$ \\
\hline Hydrochloric Acid & $\mathrm{HCl}$ & 12.1 \\
\hline \multicolumn{2}{||l}{${ }^{*}$ Concentration in Molarity. } \\
\hline \multicolumn{2}{|l|}{}
\end{tabular}

\section{Solutions}

\subsection{Hydrochloric Acid}

Add approximately $4 \mathrm{~L}$ of pure water into a plastic carboy calibrated at 8-L. Under a fume hood, slowly bring to 8-L volume with concentrated Hydrochloric Acid, and mix using a magnetic stir bar with stirrer. Alternately, any repipette container to which equal volumes of pure water and concentrated Hydrochloric Acid have been added is sufficient.

\section{Procedure}

1) Weigh 1.00 g of oven-dry, ground plant tissue into a $50-\mathrm{mL}$ beaker and place in a muffle furnance. If boron is requested, use high-form, glazed, porcelain crucibles.

a) Duplicate every 20th sample to measure the precision of the test.

b) Digest at least one external or internal plant tissue standard sample with each digestion.

2) Place samples in muffle furnace. Ensure temperature controls are set to $500^{\circ} \mathrm{C}$ and turn the furnace on.

3) Once the internal temperature of the oven reaches $500^{\circ} \mathrm{C}$, allow samples to ash for a minimum of 5 hours (ashing time should 
never exceed 16 hours). Shut oven off and allow oven to cool.

4) Once the furnace temperature is below $200^{\circ} \mathrm{C}$, carefully open the furnace door to expedite the cooling process. CAUTION: The internal temperature of the muffle furnace should be below $200^{\circ} \mathrm{C}$ before opening the furnace door so that the samples are not ignited or disturbed by the rapid influx of air.

5) Once samples reach room temperature, remove them from the oven and moisten the ash by adding approximately 5 drops of pure water using an eyedropper followed by the addition of $5 \mathrm{~mL}$ of $6 \mathrm{M}$ Hydrochloric Acid. Let this suspension stand for at least 30 minutes before proceeding.

6) With the aid of a funnel, quantitatively transfer the solution containing the ash to a 50-mL volumetric flask. Rinse beaker with pure water and transfer the rinsate to the flask also. Repeat the rinse steps a second time and then bring to volume with pure water. Mix thoroughly.

7) Transfer an aliquot of the sample to an appropriate container for analysis. If filtration is required, use a Roger's Custom Lab 620 (Whatman No. 42 equivalent) filter paper.

8) The sample solution may be analyzed using either ICP or AAS in combination with colorimetric analysis for P determination.

9) Sample results are reported in $\mathrm{mg} \mathrm{kg}^{-1}$ -plant dry weight for $\mathrm{B}, \mathrm{Cu}, \mathrm{Fe}, \mathrm{Mn}$ and $\mathrm{Zn}$ and in \%-plant dry weight for $\mathrm{P}, \mathrm{K}, \mathrm{Ca}$ and $\mathrm{Mg}$.

\section{Total Kjeldahl Nitrogen (TKN) in Plant Tissue}

The TKN method is used to analyze for nitrogen in organic materials. Most organically-bound nitrogen (such as that found amines, proteins, etc.) as well as any nitrogen in the form of ammonium ion can be determined using this method. In general, nitrates, nitrites, and some cyclic nitrogenous compounds resistant to digestion are not determined using this method. ${ }^{9}$ The Kjeldahl digestion process produces a highly acidic solution and is therefore not recommended for nitrate analysis, as it will cause damage to the instrument.

\section{Reagents}

Reagents used in this procedure are listed in Table 9.

\section{Digestion Procedure for Plant Samples}

1) Weigh $0.200+/-0.005 \mathrm{~g}$ of plant tissue onto a nitrogen-free weighing paper. Carefully fold the paper containing the sample and place into a TKN digestion tube $(25 \mathrm{~mm}$ x $200 \mathrm{~mm}$; Fisher cat. No. 14-960 F).

a) Duplicate every 20th sample to measure the precision of the test.

b) Digest at least one external or internal plant tissue standard sample with each digestion.

2) Scoop approximately $2.0 \mathrm{~g}$ of Kjeldahl digestion mixture (this mixture may be obtained from Pope Inc., Dallas, TX 75221) and transfer to the bottom of the digestion tube with the aid of a long stem funnel.

3) Carefully add $5 \mathrm{~mL}$ of concentrated Sulfuric Acid to each tube.

4) Start the digestion by placing samples in a $250^{\circ} \mathrm{C}$ preheated aluminum block digester for 1 hour.

5) After 1 hour at $250^{\circ} \mathrm{C}$, place glass funnels on all tubes and increase the digestion temperature to $365^{\circ} \mathrm{C}$. Digest samples for an additional 2.5 to 3.0 hours.

6) After digestion is complete, allow block to cool. When tubes are cool enough to handle, remove from the digestion block and place into a wire rack to cool to room temperature.

7) Using a wash bottle, add 5 to $10 \mathrm{~mL}$ of pure water washing the sides of each tube. Mix using a Vortex mixer.

8) With the aid of a funnel, transfer the contents of the tube into a $100-\mathrm{mL}$ volumetric flask. Rinse the 
Table 9. Reagents used in TKN procedure.

\begin{tabular}{||l|c|c||}
\hline \hline Name & Formula & F.W./Conc. ${ }^{*}$ \\
\hline Kjeldahl mixture No. $2\left(10 \mathrm{~g} \mathrm{~K}_{2} \mathrm{SO}_{4}+0.30 \mathrm{~g} \mathrm{CuSO}_{4}\right)$ \\
\hline Sulfuric Acid & $\mathrm{H}_{2} \mathrm{SO}_{4}$ & $18 \mathrm{M}$ \\
\hline \multicolumn{2}{||l||}{${ }^{*}$ Formula weight in grams or concentration in Molarity or percent. } \\
\hline
\end{tabular}

digestion tube several times with water and add the rinsates to the volumetric flask. Dilute to volume and mix well.

9) Allow flask to cool, dilute to volume, cover with parafilm, and mix thoroughly.

10) Transfer an aliquot of the sample to an appropriate container for analysis. If filtration is required to remove particulates, use a Roger's Custom Lab 720 (Whatman No. 2 equivalent) filter paper.

11) The ESTL uses semi-automated colorimetric analysis (EPA Method 351.2) to determine nitrogen in TKN digestates. The instrument (Alpkem autoanalyzer) is set up and calibrated as per manufacturer's directions. Instrument calibration standards and quality control samples should be digested in the same manner as the samples. Instrument results are reported to one decimal in $\mathrm{mg}$ $\mathrm{L}^{-1}$. Final results are reported as $\% \mathrm{~N}$-plant dry weight and are converted from $\mathrm{mg} \mathrm{L}^{-1}$ using the following equation:

Observed value in $\mathrm{mg} \mathrm{L}^{-1} \mathrm{x}(100 \mathrm{~mL} / 0.2$ g) $/ 10,000=\%$ TKN

\section{Quality Control}

Operations within an analytical laboratory must address quality control in order to maintain both accuracy and precision. This dedication to quality control must begin with detailed procedures and address all steps in which inaccuracies can be introduced. Efforts to control inaccuracies are directed at three levels: quantitative chemical techniques, instrument monitoring, and managerial process inspection. The ESTL's Quality Control Plan addresses each of these areas assuring that the laboratory produces high quality and reliable data. Details concerning the ESTL's Quality control procedures can be obtained by contacting the laboratory director or the manager.

\section{Laboratory Safety}

The following is a general list of safety requirements that should be followed by any person handling laboratory chemicals or working in a chemical laboratory:

1. Always wear an acid/base resistant laboratory coat.

2. Always wear goggles/eyeglasses as minimum eye protection.

3. Always wear appropriate gloves when handling chemicals.

4. Never work alone in a chemical laboratory.

5. Never eat or drink in the laboratory area.

6. Do not store food in chemical refrigerators.

7. If working with an unfamiliar chemical, always read the label and check the MSDS before proceeding.

8. Always transport concentrated acids/bases or other dangerous chemicals in a rubberized safety bucket.

9. Know where the nearest fire extinguisher and eye wash station are located.

10. Know the location of the nearest phone and how to reach 911 or the local emergency number.

11. Do not pipet chemicals by mouth.

12. Wear appropriate laboratory clothing including closed-toe shoes and long pants. Tie back long hair. 


\section{References}

1. Adams, F., and C.E. Evans. 1962. A rapid method for measuring lime requirement of red-yellow podzolic soils. Soil Sci. Soc. Am. Proc. 26:355-357.

2. Allison, L.E. 1965. Organic carbon. In C.A. Black, D.D. Evans, L.E. Ensminger, J.L. White, and F.E. Clark (ed). Methods of Soil Analysis, Part 2. pp. 1367-1378.

3. Haman, D.Z., and D.B. Bottcher. 1986. Home water quality and safety. Circ 703, UF/IFAS Coop. Extn. Ser., pp. 12.

4. Haman, D.Z., G.A. Clark, and A.G. Smajstrla. 1989. Irrigation of lawns and gardens. Circ. 825, UF/UFAS Coop. Extn. Ser., pp. 28.

5. Hochmuth, G.J. and E.A. Hanlon. 1998. Calculating fertilizer rates for vegetable crops grown in raised-bed cultural systems in Florida. Fact Sheet HS743, UF/ IFAS, Coop. Extn. Ser., pp. 4.

6. Hanlon, E.A., and G.V. Johnson. 1984. Bray/Kurtz, Mehlich III, AB/D and ammonium acetate extractions of $\mathrm{P}, \mathrm{K}$ and $\mathrm{Mg}$ in four Oklahoma Soils. Commun. Soil Sci. Plant Anal. 15(3):277-294.

7. Isaac, R.A., and J.B. Jones, Jr. 1972. Effects of various dry ashing temperatures on the determination of 13 nutrient elements in five plant tissues. Commun. Soil Sci. Plant Anal. 3:261-269.

8. Jones, Jr., J.B. (ed.). 1992. Handbook on reference methods for soil testing. Council on Soil Testing and Plant Analysis, Athens, GA.

9. Jones, J.B., Jr., and V.W. Case. 1991. Sampling, handling, and analyzing plant tissue samples. pp. 389-415. In R.L. Westerman (ed.) Soil testing and plant analysis. 3rd edition. Book Series No. 3. Soil Sci. Soc. Amer., Madison, WI.

10. Kidder, G., and E.A. Hanlon. 1998.

Neutralizing excess bicarbonates from irrigation water. Soil \& Water Science Fact Sheet 142, Coop. Ext. Serv., UF/IFAS, pp.6.
11. Magdoff, F.R., M.A. Tabatabai, and E.D. Hanlon. 1996. Soil Organic Matter: Analysis and Interpretation. Soil Sci. Spec. Pub. No. 46:21-31.

12. Mylavarapu, R., T. Yeager and J.M. Bartos. 2001. UF/IFAS Nutrient Management Series: Container Media Nutrient Test Interpretations. SL 180, Soil \& Water Science, Coop. Extension Service, pp3.

13. Mylavarapu, Rao S., J.M. Bartos. 1999. Landscape and Vegetable Garden Test Information Sheet. SL-136, Soil \& Water Science, Cooperative Extension Service, IFAS. pp3.

14. Mylavarapu, Rao S., J.M. Bartos. 1999. Producer Soil Test Information Sheet. SL-135, Soil \& Water Science, Cooperative Extension Service, IFAS. pp3.

15. Mylavarapu, Rao S., J.M. Bartos. 1999.

Container Media Test Information Sheet. SL-134, Soil \& Water Science, Cooperative Extension Service, IFAS. pp3.

16. Mylavarapu, Rao S., J.M. Bartos. 1999. Water Test Information Sheet. SL-133, Soil \& Water Science, Cooperative Extension Service, IFAS. pp3.

17. Mylavarapu, Rao S., J.M. Bartos. 1999. Pine Nursery Soil Test Information Sheet. SL-132, Soil \& Water Science, Cooperative Extension Service, IFAS. p2.

18. Mylavarapu, Rao S., J.M. Bartos. 1999. Plant Tissue Test Information Sheet. SL-131, Soil \& Water Science, Cooperative Extension Service, IFAS. p2.

19. Nelson, D.W., and L.E. Sommers. 1982. Total carbon, organic carbon, and organic matter. pp. 539- 579. In A.L. Page, R.H. Miller, and D.R. Keeney (ed.). Methods of soil analysis: Part 2. 2nd. Edition. Book Series No. 9. Amer. Soc. Agron. Madison, WI.

20. Soltanpour, P.N. 1991. Determination of nutrient availability and elemental toxicity by AB-DTPA soil and ICPS. In B.A. Stewart (ed.) Advances in Soil Science. 16:165-190. 
21. Southern Region Information and Exchange

Group on Soil Testing and Plant Analyses

(SRIEG 18). 1983. Reference soil test methods

for the Southern region of the United States.

Southern Cooperative Series Bull. 289. Univ. of

Georgia, Athens, GA.

22. U.S. Environmental Protection Agency. 1984.

Methods for Chemical Analysis of Water and

Wastes, March, EPA-600/4-79-020,

Environmental Monitoring and Support

Laboratory, Office of Research and

Development, Cincinnati, OH 45286.

\section{Acknowledgements}

The authors would like to express their appreciation to the following people for their technical assistance in the preparation of this manual:

J. DeVore, L. Moon, P. Reynolds, S. Robinson, C. Simmons, P.Straub, A. Tyer, and B. Welch. 